\title{
Evaluation of Probiotic-Fermented Feed Addition and Laser- Firing to Accelerate Mature Broodstocks and Seed Productions of African Catfish (Clarias gariepinus)
}

\author{
Pungky Slamet Wisnu Kusuma ${ }^{1}\left(\mathbb{D}\right.$, Dyah Hariani $^{2}{ }^{(}$, Akhmad Taufiq Mukti $^{3, *} \mathbb{C}$
}

\begin{abstract}
${ }^{1}$ Study Program of Biology, Faculty of Technology Science, Universitas PGRI Adi Buana, Jl. Ngagel Dadi IIIB/37 Wonokromo, Surabaya, East Java, Indonesia.

${ }^{2}$ Study Program of Biology, Faculty of Mathematic and Natural Science, Universitas Negeri Surabaya, Jl. Ketintang Wiyata 48, Gayungan, Surabaya, East Java, Indonesia.

${ }^{3}$ Department of Aquaculture, Faculty of Fisheries and Marine, Universitas Airlangga, Kampus C Unair, Jl. Mulyorejo Surabaya, East Java, Indonesia.
\end{abstract}

\section{How to cite}

Kusuma, P.S.W., Hariani, D., Mukti, A.T. (2022). Evaluation of Probiotic-Fermented Feed Addition and Laser-Firing to Accelerate Mature Broodstocks and Seed Productions of African Catfish (Clarias gariepinus). Turkish Journal of Fisheries and Aquatic Sciences, 22(2), TRJFAS19303. http://doi.org/10.4194/TRJFAS19303

\section{Article History}

Received 21 February 2021

Accepted 22 September 2021

First Online 27 September 2021

\section{Corresponding Author}

E-mail: akhmad-t-m@fpk.unair.ac.id

\section{Keywords}

Fermented feed

Probiotics

Soft-laser

Gonadal maturity

African catfish

\begin{abstract}
This study aimed to determine the effects of fermented feed using probiotics and laser-firing to accelerate the mature broodstocks and seed productions of African catfish (Clarias gariepinus). Fish has used male and female broodstocks of catfish. The method was used a completely randomized design with three treatments: unfermented feed as control, probiotic-fermented feed (PFF), and probioticfermented feed+laser firing (PFF+Li). In the first study, a laser-firing dose of 1.125 Joule was performed on fish broodstocks every 15 days. The gonadal maturity time of male and female broodstocks was observed. The second study, treated female broodstocks, was mated with mature male broodstocks without any prior treatments (control). Fertilization rate, hatching rate, and seed production performances such as survival rate and total length were measured. The results showed that treatment of PFF+Li has a significant effect $(P<0.05)$ on the gonadal maturity time of males and females. This treatment reaches the fastest time to mature of the female gonad (31-41 days) and the male gonad ( $32-37$ days) than other treatments $(P<0.05)$. This treatment also produced the highest fertilization, hatching, and survival rates of more than $90 \%$, respectively, and the highest seed yield of $2.1-3.0 \mathrm{~cm}$ size compared to other treatments $(P<0.05)$ in African catfish.
\end{abstract}

\section{Introduction}

The main problem faced by catfish breeders in hatchery centers is the conventional cultivation method. Catfish that have spawned need recovery time to generate around three months later. Thus the availability of broodstocks and seeds in the community is limited and not continuous to hinder the productivity catfish farming business. The market demand for this catfish commodity continues to increase; meanwhile, the availability of gonadal mature and catfish seeds is decreasing. It is necessary to find alternative solutions through more intensive catfish farming, namely by increasing feed quality and applying appropriate biostimulation laser technology to mature broodstocks.

Generally, the protein content in catfish feed could affect several things, such as gonadal development, spermatozoa, and eggs productions limit number and quality. Based on study according to Coldebella et al. (2011) showed that the protein content of the feed was proven to affect the survival of larvae, to deficient levels of feed protein content (10 to $20 \%$ ), resulting in low 
fertilization rate of eggs and a higher percentage of abnormal larvae. Bromage (1995) stated that nutrition considerably affects gonadal development and reproductive performance in fish. The lacking of lipids, proteins, fatty acids, vitamins $\mathrm{C}$ and $\mathrm{E}$, and carotenoids in the diet produced the more inferior quality of fish eggs because these components influence various reproduction processes such as fertility of eggs and the hatching rate of the embryo, and survival rate of larvae. Hence, the quality of feed in the broodstocks needs to be improved.

According to Sakamole et al. (2014), the study results showed that the probiotics in feed could break down feed complex compounds into simple ones. The digestive enzymes such as amylase, protease, lipase, and cellulase could increase the feed's nutritional value and digestibility. Elumalai et al. (2013) stated that probiotics are live microorganisms that could prevent disease in cultured fish, increase production, and reduce economic losses in fish cultivators. The addition of probiotics in the feed also improves immunity, which affects the survival of the cultured fish.

Another vital role of probiotics is to improve reproductive performance. The first study was about the effects of probiotics on the reproductive performance in ornamental fish, according to Ghosh et al. (2007). Several studies have shown the effect of probiotics on fish reproduction as according to Abasali and Mohamad (2010), Giorgini et al. (2010), Gioacchini et al. (2013), Ariole (2012), Miccoli et al. (2015), Carnevali et al. (2017), Mehdineja et al. (2018), and Rahman et al. (2018), both males and females. Probiotics affect the integrated control of fish metabolism, the development of the gonad, and the quality of gametes in zebrafish, Danio rerio (Carnevali et al., 2017). Probiotics also have beneficial effects on stimulating gonadal development, gonadosomatic index (GSI), maturation, gametes quality, and survival of butter catfish, Ompok pabda larval (Rahman et al., 2018).

On the other hand, the effects of laser have been investigated in several species of fish, such as African catfish (Kusuma et al., 2015), striped catfish, Pangasianodon hypophthalmus (Mukti et al., 2020b) and mud crab, Scylla serrata (Kusuma et al., 2007). The use of laser technology has been successfully developed by catfish farmers in East Java and Central Java. Laser firing for 15 seconds (dose of 1.125 Joule) at the reproductive point, precisely at $2 / 3$ of the ventral body with the frequency of once in two weeks, both a single treatment and combination with different feed protein have optimal accelerated gonadal growth, development, and maturation time of catfish broodstocks (Hariani \& Kusuma, 2019; Hariani et al., 2020). Laser firing optimally affects the increase in the activity of neurotransmitters and neurohormones. The increased neurohormones are shown by synthesizing gonadotropin-releasing hormone $(\mathrm{GnRH})$ in the hypothalamus and released in the pituitary (Kusuma \& Hariani, 2019). Therefore, based on previous study experiences, this study aimed to determine the effects of adding the fermented feed using probiotic and laser firring on accelerating the mature broodstocks and seed productions of African catfish.

\section{Materials and Methods}

This study was conducted at the UPT PTPBP2KP Malang, East Java, Indonesia. This study was used experimentally with a completely randomized design consisting of three treatments and three-time replicates. This study was performed through two steps: testing the effect of treatments on gonadal maturity time of male and female broodstocks (first study) and evaluating the performance of seed produced from treated female broodstocks (second study).

\section{Animals}

The I gonadal maturity stage male and female broodstocks of African catfish with the average age of 1 to 1.5 years and the average body weight (BW) of $1500 \pm 100 \mathrm{~g}$ were used. In this study, the experimental protocols were approved by the Scientific Committee with Protocol Number 027/SP2H/AMD/LT/MULTI/L7/2 020.

\section{Feed and Probiotic}

In this study, the commercial feed contains $38 \%$ crude protein was used. The commercial feed was fermented using a commercial probiotic on the market (Probio-7) dose of $5 \mathrm{~mL} \mathrm{~kg}{ }^{-1}$ as fermenter produced by Tamasindo Veterinary. Probio-7 consists of fungi (Saccharomyces cerevisiae and Aspergillus oryzae) and bacteria (Lactobacillus acidophilus, Bacillus subtilis, Rhodopseudomonas, Actinomycetes, and Nitrobacter) containing more than $1 \times 10^{11} \mathrm{CFU} \mathrm{L}^{-1}$, respectively.

\section{First Study: Rearing of Fish Broodstocks}

The broodstocks (males and females) were acclimatized separately and fed commercial feed for two weeks in a controlled pond size of $2 \mathrm{~m} \times 2 \mathrm{~m} \times 0.9$ $m$ to prevent spawning before treatment. Next, the broodstocks were treated using three treatments: unfermented feed as control, probiotic-fermented feed (PFF), and probiotic-fermented feed+laser firing (PFF+Li). The broodstocks were fed twice (morning and evening) and $5 \%$ of the BW until the fish gonad were matured.

\section{Laser Firing}

The laser was used as a diode soft-laser of $15 \mathrm{~mW}$ with a wavelength of $532 \mathrm{~nm}$ equivalent with 1.125 Joule is still in the safe range for biostimulation of biological organs. The laser firing was conducted at the reproductive acupoint of fish broodstocks, precisely in 
$2 / 3$ of the body ventral part for 15 seconds (Kusuma et al., 2015), every 15 days until the mature gonad (the IV maturity stage) and is ready to be spawned.

\section{Measurement of Gonadal Maturity}

The gonadal maturity of broodstocks, both males and females, were observed once every 2 to 5 days to determine the gonadal maturity time after treatment. The gonadal maturity was marked to spawning behavior signs and genitalia visually of catfish.

\section{Second Study: Spawning and Eggs Incubation}

Only female broodstocks from the treatments were used in the second study, while mature male broodstocks were used as parent couples without any prior treatments (control). Then, the one pair of mature broodstocks was reared and mated at the spawning pond size of $2 \mathrm{~m} \times 2 \mathrm{~m} \times 0.9 \mathrm{~m}$ separately between treatments. Fish spawning was conducted to spawning pond using a substrate size of $1.4 \mathrm{~m} \times 0.4 \mathrm{~m}$ to the eggs attachment and aerations to the supply dissolved oxygen during eggs incubation, separated between treatments. During the spawning process, fish has fasted. After 8 hours, the broodstock completes the spawning process. Then, the substrate size $0.3 \mathrm{~m} \times 0.3$ $\mathrm{m}$ was quoted as a sample to count the number of fertilized eggs manually and incubated at the controlled aquarium size of $0.5 \mathrm{~m} \times 0.5 \mathrm{~m} \times 0.5 \mathrm{~m}$ with good aeration until hatching, separated between treatments. The eggs qualities of spawned catfish, such as fertilization rate (FR) and hatching rate $(H R)$, were measured. The formulas were used to calculate FR and $H R$, respectively, as follows:

$$
\begin{aligned}
& \text { Fertilization rate }(\%)=\frac{\text { Number of fertilized eggs }}{\text { Total number of eggs }} \times 100 \\
& \text { Hatching rate }(\%)=\frac{\text { Number of eggs hatched }}{\text { Total number of fertilized eggs }} \times 100
\end{aligned}
$$

\section{Rearing of Seed}

The catfish fry of three days after hatching (dah) was reared at the controlled pond size $2 \mathrm{~m} \times 2 \mathrm{~m} \times 1 \mathrm{~m}$, separated between treatments with a density of 100,000 fish, respectively, for three months. The fry was fed gradually. The fry was fed a silkworm, at-satiation, three times a day for one month. Next, the seed was fed commercial feed contains $35 \%$ crude protein for one month; continued commercial feed had $35 \%$ crude protein until end rearing as much as $5 \%$ of the biomass, three times a day. The formulas used to calculate survival rate (SR), according to Mukti et al. (2020a), are as follows:

$$
\text { Survival rate }(\%)=\frac{\text { Life fish number at he final of rearing }}{\text { Life fish number at he initial of rearing }} \times 100
$$

\section{Measurement of Survival and Total Length}

The mortality of seed was observed and counted every day. At the end of rearing, the SR and the total length (TL) were measured. The seed was sorted and grouped into two grades of TL, i.e., 1.0 to $2.0 \mathrm{~cm}$ and 2.1 to $3.0 \mathrm{~cm}$, respectively.

\section{Data Analysis}

Data on gonadal maturity time of broodstocks (first study), FR, HR, SR, and TL grades of seed (second study) were statistically analyzed using variant (ANOVA) analysis with SPSS ver. 18 software (SPSS Inc., Chicago, IL, USA). Followed by Duncan's multiple range test with a confidence level of $95 \%$, according to Mukti et al. (2020a, b).

\section{Ethical Statement}

All authors declare that the present study was conducted in an ethical, professional, and responsible manner.

\section{Results}

\section{Gonadal Maturity Time of Broodstocks}

The results showed that the addition of probioticfermented feed and laser-firing (PFF+Li) in the broodstocks before spawned have a significant effect $(P<0.05)$ on the gonadal maturity time of males and females catfish. The gonadal maturity time of PFF+Li treatment was significantly fastest (32 to 37 days) compared to PFF and control treatments $(P<0.05)$, as shown in Figures 1 and 2. Laser firing accelerates the gonadal maturity time of 1.68 and 1.26 times faster than control and PFF treatments. In contrast, PFF treatment accelerates the gonadal maturity time of 1.34 times faster than control.

\section{Seed Production}

The results indicated that the FR, HR, SR, dan seed size production had significant differences between treatments $(P<0.05)$. The PFF+Li treatment has the FR, $H R$, and SR highest compared to other treatments, as shown in Figures 3, 4, and 5, respectively. This study indicated that laser firing increases FR and HR of eggs and $S R$ of seed in catfish. Meanwhile, the addition of fermented feed increases the FR, HR, SR, and significant differences than control $(P<0.05)$.

The results also showed that the addition of probiotic-fermented feed and laser-firing have significant differences $(P<0.05)$ on size grades of catfish seed after being reared for three months. This study indicated that the PFF+Li treatment produces the seed number of 2.1 to $3.0 \mathrm{~cm}$ size highest compared to other treatments with a ratio between 1.0 to $2.0 \mathrm{~cm}$ and 2.1 




Figure 1. Gonadal maturity time of male catfish broodstocks between treatments. PFF = probiotic-fermented feed, PFF+Li $=$ probiotic-fermented feed+laser firing. Mean values not sharing the same letter indicate significant difference $(P<0.05)$.

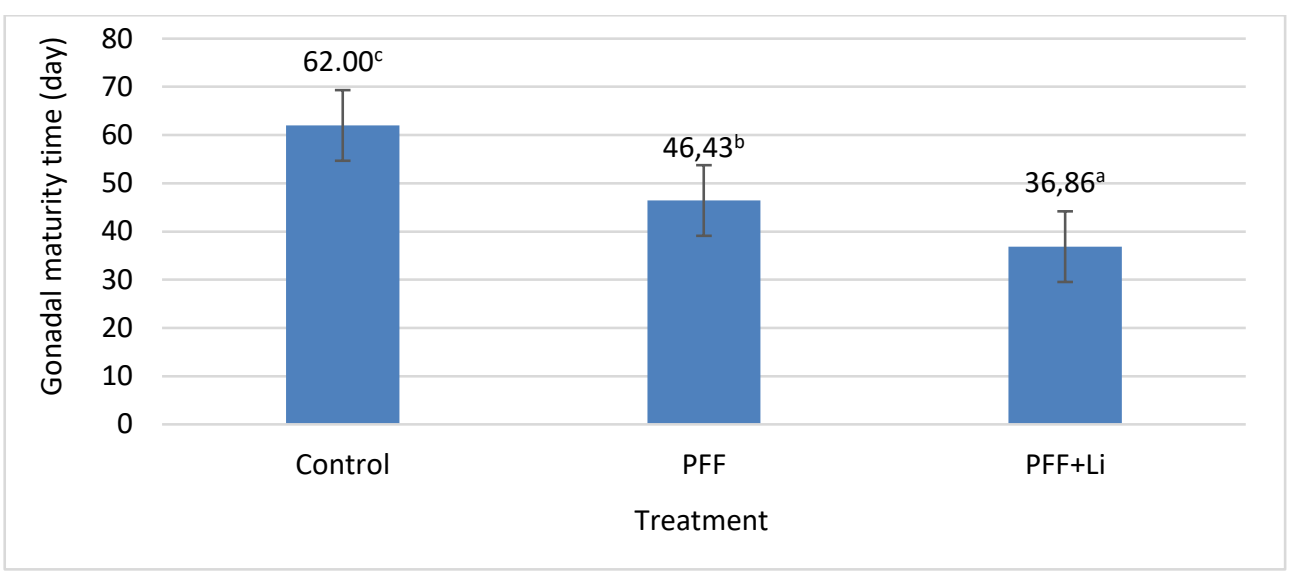

Figure 2. Gonadal maturity time of female catfish broodstocks between treatments. $P F F=$ probiotic-fermented feed, $P F F+L i=$ probiotic-fermented feed+laser firing. Mean values not sharing the same letter indicate significant difference $(P<0.05)$.

to $3.0 \mathrm{~cm}$ sizes was $1: 2.64$. In control, a ratio between 1.0 to $2.0 \mathrm{~cm}$ and 2.1 to $3.0 \mathrm{~cm}$ sizes was $1: 2.53$, while PFF treatment has the same relative ratio between 1.0 to $2.0 \mathrm{~cm}$ and 2.1 to $3.0 \mathrm{~cm}$ sizes (Figure 6).

\section{Discussion}

Probiotics have been used to improve reproductive performances in many species, both land and aquatic animals. Several studies showed that probiotics increase eggs production of laying hens (Mikulski et al., 2012). Probiotics can also improve reproductive health and performance in the human (Reid et al., 2013; Younis \& Mahasneh, 2020). In fishes, diet supplementation with probiotics can accelerate fecundity and offspring immunity of zebrafish (Qin et al., 2013), gonadosomatic index, and ovarian growth phase of zebrafish (Gioacchini et al., 2011), and fry production of live-bearing ornamental fish (Ghosh et al., 2007). The addition of probiotics in the feed also increases egg diameter, fecundity, fertilization, and hatching rates eyed eggs and alevins survival rates in rainbow trout, Oncorhynchus mykiss (Nargesi et al., 2018), and Nile tilapia, Oreochromis niloticus (Dias et al., 2020).
This study indicated that the addition of probiotics as fermenters in commercial feed was proven to accelerate the gonadal maturity time of male dan and female African catfish. Male and female broodstocks of catfish treated probiotic-fermented feed (PFF) show a faster maturity time in the gonad than unfermented feed (control). This result indicated that the addition of probiotics could increase the nutrition value of the feed. Probiotics can produce several digestive enzymes, such as amylase, protease, lipase, and cellulose. These enzymes were advantageous in hydrolyzing carbohydrates, proteins, and fats of commercial feed into simpler molecules, facilitating the digestion and absorption processes in the digestive tract of catfish. Also, several studies showed that bacteria present in probiotics could increase the nutritional value of feed by synthesizing vitamins, proteins, essential fatty acids, amylase, protease, and lipase enzymes (Irianto \& Austin, 2002; Ghosh et al., 2008).

The probiotic-fermented commercial feed using Probio-7 contains several non-essential amino acids, such as alanine, asparagine, aspartate, glutamate glycine, serine, and tyrosine (Kusuma \& Hariani, 2019). Glutamate is one amino acid that plays an influential 


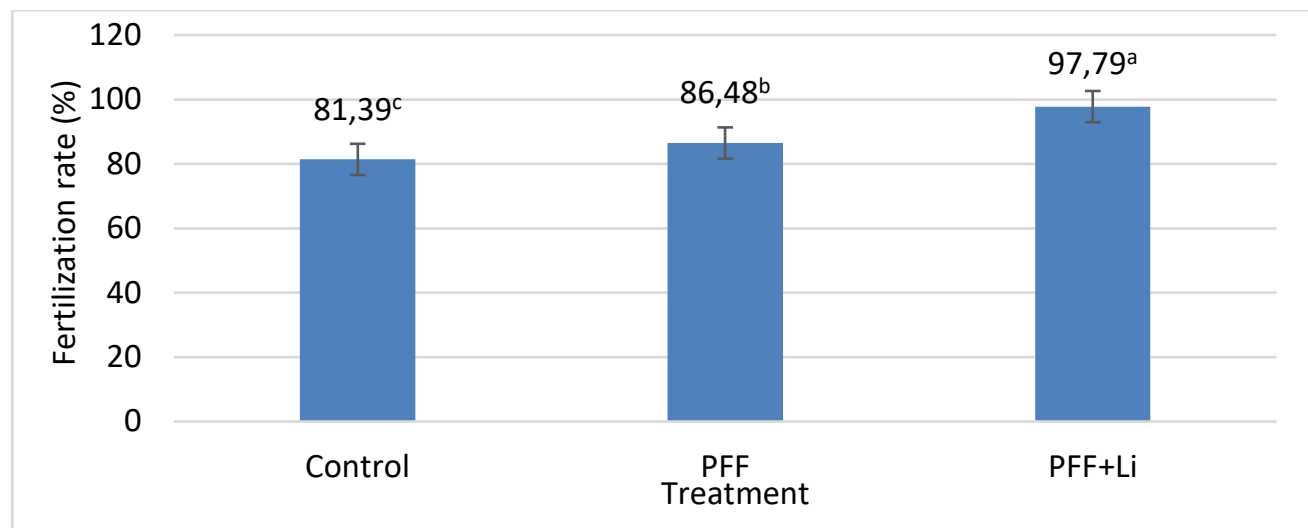

Figure 3. Fertilization rate of catfish eggs between treatments. $\mathrm{PFF}=$ probiotic-fermented feed, $\mathrm{PFF}+\mathrm{Li}=$ probiotic-fermented feed+laser firing. Mean values not sharing the same letter indicate significant difference $(P<0.05)$.

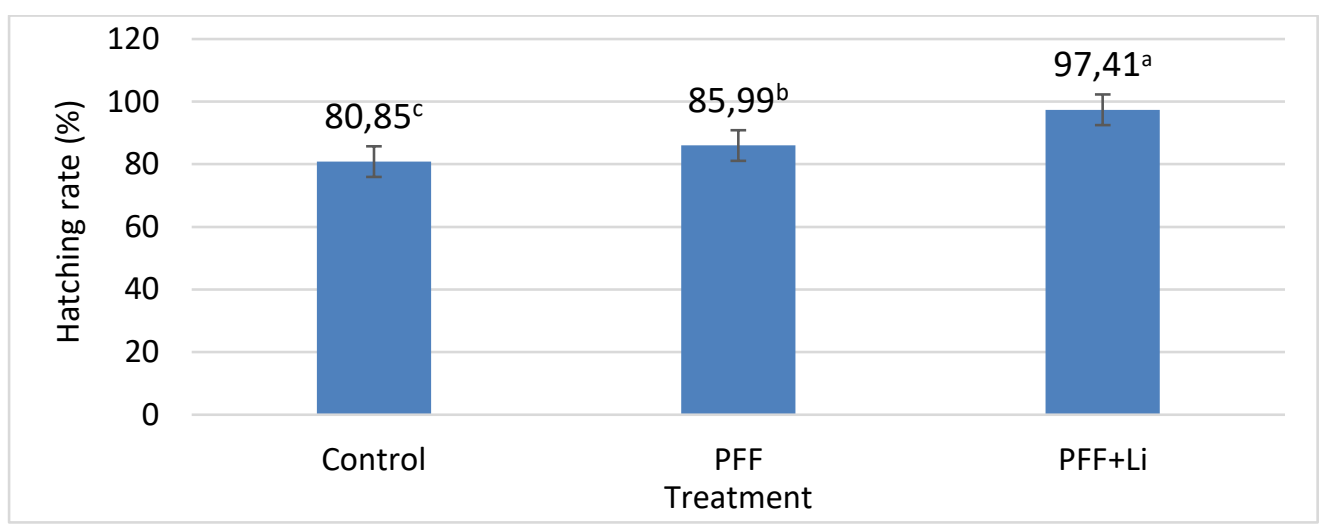

Figure 4. Hatching rate of catfish eggs between treatments. $\mathrm{PFF}=$ probiotic-fermented feed, $\mathrm{PFF}+\mathrm{Li}=$ probiotic-fermented feed+laser firing. Mean values not sharing the same letter indicate significant difference $(P<0.05)$.

role as a primary transmitter in the fish brain, which functions as a mediator to transmit signals in postsynaptic. This glutamate also works as a precursor to the neurotransmitter Gamma-aminobutyric acid (GABA). So, suppose probiotic-fermented feed is given and combined with laser-firing on the catfish broodstocks. In that case, there will be a physiological reaction in the body of the main fish in the brain. This study indicated that laser firing has that effect. Where GABAergic neurons that were not active before become reactive due to the activity of the GAD-65 enzyme. GABAergic would synthesize GABA. GABA stimulates the gonadotropin-releasing hormone $(\mathrm{GnRH})$ synthesized from the hypothalamus and pituitary. GnRH plays a role in facilitating the synthesis and release of folliclestimulating hormone (FSH) and Luteinizing hormone (LH) (GtH-I and GtH-II). This molecular activity can occur because there is a relationship between neurons in the catfish broodstocks brain induced by laser (Kusuma \& Hariani, 2017). The use of the laser has also been widely applied to chicken (Binawati, 2008) and sheep (Herdis, 2010).

The release of GtH-I in female catfish stimulates the gonads to produce steroid hormones such as estradiol-17 $\beta$. Then, the bloodstream carried Estradiol$17 \beta$ produced by granulose cells from ovarian follicles to hepatic hepatocytes. Estradiol-17 $\beta$ will have the effect of stimulating vitellogenesis to synthesize and release vitellogenin. Then vitellogenin was carried by the bloodstream to developing oocytes to be absorbed and accumulated, and as a result, the oocytes will increase in diameter and mature (Kusuma \& Hariani, 2019). Sabet et al. (2009) and Taghizadeh et al. (2013) stated that the same thing that changes in estradiol-17 $\beta$ levels in blood plasma were closely related to oocyte development. The release of $\mathrm{GtH}-\mathrm{Il}$ plays a role in stimulating the final maturation of gonads, ovulation, and spawning of female catfish. Arukwe and Goks $\varnothing$ yr (2003) stated that the synthesis process of the yolk protein precursor was vitellogenin due to the stimulation of estradiol-17 $\beta$. Vitellogenin was secreted in the liver and then carried by the bloodstream to the developing ovary for absorption.

Large and mature oocytes were developed by increasing the hepatosomatic index (HSI) and GSI (Cerda et al., 2007; Hariani \& Kusuma, 2019). The value of HSI and GSI reached a maximum before spawning and then decreased after spawning (Araoye, 2001; Laleye et al., 2006; Shinkafi \& Ipinjolu, 2012). Nutrition in brood fish feed was studied because biological mechanisms, such as gonad maturity, were complicated. Gonadal development and fecundity are influenced by several 


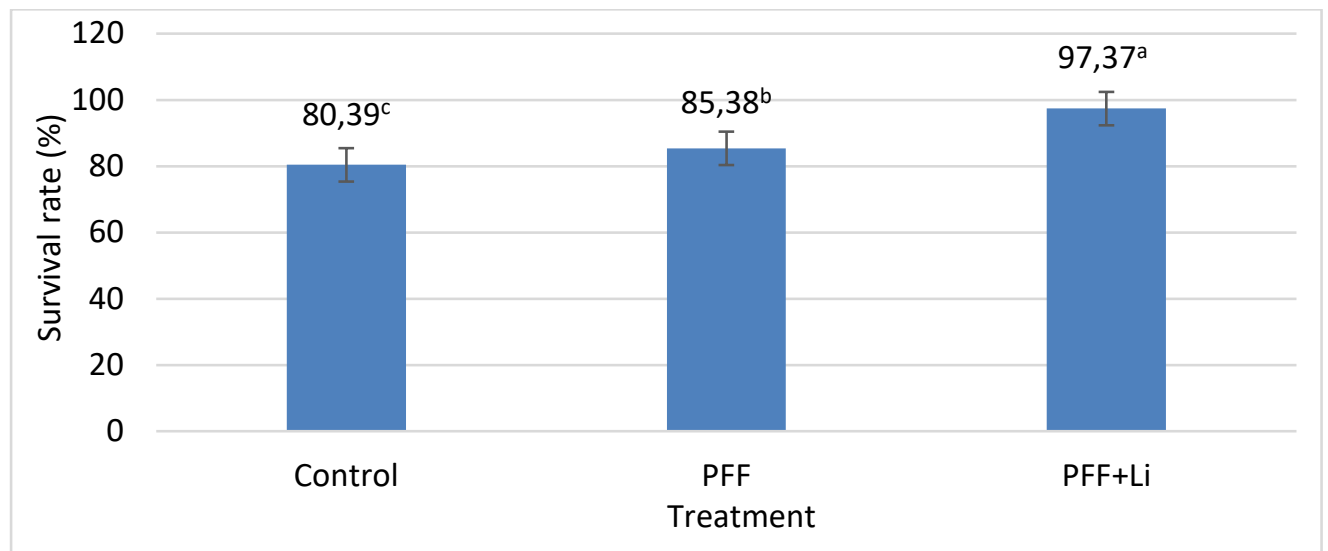

Figure 5. The survival rate of catfish seed between treatments. $\mathrm{PFF}=$ probiotic-fermented feed, $\mathrm{PFF}+\mathrm{Li}=$ probiotic-fermented feed+laser firing. Mean values not sharing the same letter indicate significant difference $(P<0.05)$.

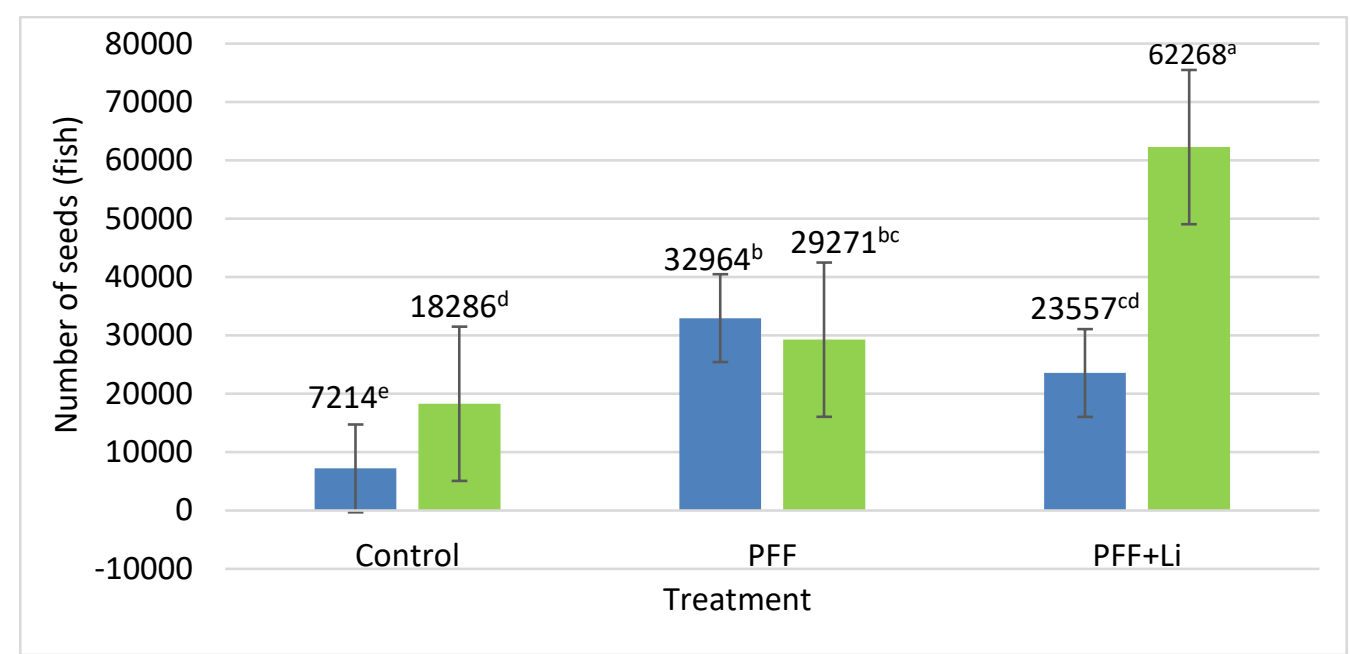

Figure 6. The number of catfish seeds with two grades of total length size produced by different treatments. PFF $=$ probioticfermented feed, $\mathrm{PFF}+\mathrm{Li}=$ probiotic-fermented feed+laser firing (blue bar = grade of 1.0 to $2.0 \mathrm{~cm}$, green bar = grade of 2.1 to 3.0 $\mathrm{cm})$. Mean values not sharing the same letter indicate significant difference $(P<0.05)$.

nutrients, especially those associated with fish spawning (Izquierdo et al., 2001).

The effect of nutrition in fish feed was substantial in gonad maturation and egg development. Proteins and lipids were the main components of egg yolk, which function as the primary source of nutrition during embryogenesis. Their existence is needed to support the survival of embryos and larvae so that they are resistant to changes in the aquatic environment (Izquierdo et al., 2001). Brooks et al. (1997) stated that protein in feed affects the protein in fish eggs, such as lipoproteins, hormones, and enzymes, all of which determine egg quality. The quality of these eggs will determine seed production on a large scale. In general, the nutritional status of fish feed could influence gonad development and limit the number and quality of eggs and sperm produced. Coldebella et al. (2011) mentioned that the protein content in broodstock feed was proven to affect the survival of larvae. If the protein content in the feed is shallow (10 to 20\%), it can result in a low egg fertilization rate and a more significant percentage of abnormal larvae.
Egg yolk protein plays a role in embryogenesis and food reserves before catfish seeds find their food. Tang and Affandi (2000) and Salerno et al. (2002) stated that vitellogenin is a glycophosphoprotein containing $20 \%$ lipid, especially phospholipids, triglycerides, lipoproteins, and cholesterol. These protein molecules were crucial because they were used as a source of energy in the growth and development of the embryo into larvae-vitellogenin synthesis characterized by increased cytoplasm volume originating from outside the cell, namely the yolk. Therefore, the egg quality is determined during vitellogenesis. Several factors such as feed quality, environment, and activity of gonadotropin hormones were very influential in supporting the success of this process. Feed quality, a supportive environment, and gonadotropin hormone activity significantly determined the egg's quality. The egg's quality produced was determined by the yolk quality protein in the oocytes. The protein could increase the number of fertilized eggs, and the high number of eggs hatch into larvae. 
The mechanism could be explained as follows: first, commercial feed containing carbohydrate, protein, fat, vitamins, minerals, fiber, and water when added with probiotics and brooded for a day, the feed will immediately be fermented into a fermented feed. The fermented feed had an acidic $\mathrm{pH}$. If this fermented feed enters the fish's digestive system, it will stimulate the gastric epithelium to increase hormone synthesis and release digestive enzymes. Digestive enzymes released in the digestive tract function to degrade fermented feed into amino acids, so easily absorbed by the intestinal epithelium by endocytosis. The bloodstream carried the nutrients that were readily absorbed to the liver, brain, and gonads from the intestinal epithelium. In the liver, the nutrients are used as a basis for the synthesis of vitellogenin. In the brain, the nutrients are used to increase neurotransmitters and neurohormones. In contrast, in the ovaries, nutrients use for the development and maturation of eggs. In the testis, nutrients play a role in steroidogenesis and gametogenesis for spermatozoa formation.

\section{Conclusion}

The combination of probiotic-fermented feed addition and laser-firing accelerates the gonadal maturity time of male and female broodstocks. It increases fertilization rate, hatching rate, survival rate, and seed size production of African catfish.

\section{Ethical Statement}

Ethical statement is not required.

\section{Funding Information}

This study was supported by the Directorate of Research and Community Service of the Directorate General of Research and Development Strengthening of the Ministry of Research, Technology, and Higher Education through the Applied Research Grants with Numbers 026/SP2H/LT-MULTI/LL7/2020 and 027/SP2H/AMD/LT/MULTI/L7/2020.

\section{Author Contribution}

PSWK collected the materials, performed the experiment, measured parameters, analyzed the data, and wrote the manuscript; $\mathrm{DH}$ collected the materials, performed the experiment, and measured parameters; ATM designed and analyzed the data, edited and corrected the manuscript. All authors read and approved the final manuscript.

\section{Conflict of Interest}

The authors declare that they have no conflict of interest.

\section{Acknowledgements}

The authors would like to thank the Directorate of Research and Community Service of the Directorate General of Research and Development Strengthening of the Ministry of Research, Technology, and Higher Education, Republic of Indonesia. The authors also would like to thank the Head and staff of the UPT PTPBP2KP, Kepanjen, Malang, East Java, Indonesia, for providing African catfish broodstocks and facilities for study. The authors would also like to thank the comments, corrections, and suggestions given by the reviewers, editor, and proofreaders to improve this article.

\section{References}

Abasali, H., \& Mohamad, S. (2010). Effect of dietary supplementation with probiotics on reproductive performance of female live-bearing ornamental fish. Research Journal of Animal Sciences, 4(4), 103-107.

Araoye, P.A. (2001). Morphology of the gonads in the reproductive cycle of Synodontis schall (Pisces: Mochokidae) in Asa Lake, Ilorin, Nigeria. Journal of Aquatic Science, 16(2), 105-110. https://doi.org/10.4314/jas.v16i2.20014

Ariole, C.N., \& Okpokwasili, G.C. (2012). The effect of indigenous probiotics on egg hatchability and larval viability of Clarias gariepinus. Revista Ambiente \& Água An Interdisciplinary Journal of Applied Science, 7(1), 8188. https://doi.org/10.4136/ambi-agua.712

Arukwe, A., \& Goksøyr, A. (2003). Review. Eggshell and egg yolk proteins in fish: hepatic proteins for the next generation: oogenetic, population, and evolutionary implications of endocrine disruption. Comparative Hepatology, 2(4), 1-21. https://doi.org/10.1186/14765926-2-4

Binawati, K. (2008). The effects of laserpuncture on egg quality of Arabian laying hens. Journal of Science, 1(2), 28-34.

Bromage, N.R. (1995). Broodstock management and seed quality-General considerations. In N.R., R.J. Roberts (Eds.). Broodstock management and egg and larval quality (pp. 1-25). Blackwell Science, UK.

Brooks, S., Tyler, C.R., \& Sumpter, J.P. (1997). Egg quality in fish: What makes a good egg. Reviews in Fish Biology and Fisheries, 7, 387-416. https://doi.org/10.1023/A:1018400130692

Carnevali, O., Maradonna, F., \& Gioacchini, G. (2017). Integrated control of fish metabolism, wellbeing, and reproduction: The role of probiotic. Aquaculture. https://doi.org/ 10.1016/j.aquaculture.2016.03.037

Cerda, J., Fabra, M., \& Raldua, D. (2007). Physiological and molecular basis of fish oocyte. In P. J. Babin, J. Cerda, E. Lubzens (Eds.). The fish oocyte, from basic studies to biotechnological applications (pp. 350-387). Springer, Dordrecht.

Coldebella, I.J., Neto, J.R., Mallmann, C.A., Veiverberg, C.A., Bergamin, G.T., Pedron, F.A., Ferreira, D., \& Barcellos, L.J.G. (2011). The effects of different protein levels in the diet on reproductive indexes of Rhamdia quelen females. Aquaculture, 312, 137-144. https://doi.org/10.1016/j.aquaculture.2010.12.021 
Dias, D. de C., Furlaneto, F. de P.B., Sussel, F.R., Tachibana, L., Gonçalves, G.S., Ishikawa, C.M., Natori, M.M., \& RanzaniPaiva, M.J.T. (2020). Economic feasibility of probiotic use in the diet of Nile tilapia, Oreochromis niloticus, during the reproductive period. Acta Scientiarum. Animal Sciences, 42, e47960. https://doi.org/10.4025/actascianimsci.v42i1.47960

Elumalai, M., Antunes, C., \& Guihernio, L. (2013). Effects of single metals and selected enzymes of Carcinus maens. Water, Air, and Soil Pollution, 141(1-4), 273-280. https://doi.org/10.1023/A:1021352212089

Ghosh, S., Sinha, A., \& Sahu, C. (2007). Effect of probiotic on reproductive performance in female live-bearing ornamental fish. Aquaculture Research, 38, 518-526. https://doi.org/10.1111/j.1365-2109.2007.01696.x

Ghosh, S., Sinha, A., \& Sahu, C. (2008). Dietary probiotic supplementation in growth and health of live-bearing ornamental fishes. Aquaculture Nutrition, 14, 289-299. https://doi.org/10.1111/j.1365-2095.2007.00529.x

Gioacchini, G., Lombardo, F., Merrifield, D.L., Silvi, S., Cresci, A., Avella, M.A. \& Carnevali, O. (2011). Effects of probiotics on zebrafish reproduction. Journal of Aquaculture Research \& Development, S1. https://doi.org/10.4172/2155-9546.S1-002

Gioacchini, G., Dalla Valle, L., Benato, F., Fimia, G.M., Nardacci, R., Ciccosanti, F., Piacentini, M., Borini, A., \& Carnevali, O. (2013). Interplay between autophagy and apoptosis in the development of Danio rerio follicles and the effects of a probiotic. Reproduction, Fertility and Development, 25(8), 1115-1125. https://doi.org/10.1071/RD12187

Giorgini, E., Conti, C., Ferraris, P., Sabbatini, S., Tosi, G., Rubini, C., Vaccari, L., Gioacchini, G., \& Carnevali, O. (2010). Effects of Lactobacillus rhamnosus on zebrafish oocyte maturation: An FTIR imaging and biochemical analysis. Analytical and Bioanalytical Chemistry, 398(7- 8), 30633072. https://doi.org/10.1007/s00216-010-4234-2

Hariani, D., \& Kusuma, P.S.W. (2019). Combination of feed protein level and laserpuncture induction of broodstock catfish (Clarias sp.) to increase estrogen, vitellogenin, and egg quality. Eurasian Journal of Biosciences, 13, 769779.

Hariani, D., Rahayu, D.A., \& Kusuma, P.S.W. (2020). Gonadstimulating potential of laserpuncture induction on the male African sharp tooth catfish (Clarias gariepinus). Egyptian Journal of Aquatic Biology \& Fisheries. 25(3), 1013-1025.

Herdis. (2010). Application of laserpuncture technology to increase the libido of Garut's male sheep (Ovis aries). Technology Center for Agriculture Production, BPPT, Jakarta.

Irianto, A., \& Austin, B. (2002). Probiotics in aquaculture. Journal of Fish Disease, 25, 633-642. https://doi.org/ 10.1046/j.1365-2761.2002.00422.x

Izquierdo, M.S., Fernández-Palacios, H., \& Tacon, A.G.J. (2001). Effect of broodstock nutrition on reproductive performance of fish. Aquaculture, 197, 25-42. https://doi.org/ 10.1016/S0044-8486(01)00581-6

Kusuma, P.S.W., \& Hariani, D. (2017). The role of laserpuncture exposure on gonad maturation mechanism of catfish (Clarias sp.) through $\mathrm{Ca}^{2+}$, PKC, and GABA neurotransmitter. Eqyptian Journal of Aquatic Research, 43, 303-305. https://doi.org/10.1016/ j.ejar.2017.10.006

Kusuma, P.S.W., \& Hariani, D. (2019). Biological study of increasing vitellogenin level and gonado somatic index by laserpuncture exposure at any protein level of dietary on catfish broodstock (Clarias sp.). Eurasian Journal of Biosciences, 13, 177-183.

Kusuma, P.S.W., Hariani, D., Mukti, A.T., \& Agustini, M. (2007). The role of laser technology as biostimulator to maturation of mud crab (Scylla serrata) eggs. Jurnal Penelitian Perikanan, 10(1), 87-91. [in Indonesian]

Kusuma, P.S.W., Ngadiani, \& Hariani, D. (2015). Utilization of laserpuncture induction as spawning stimulation in catfish (Clarias spp.) crossbreeding toward egg quality. Eqyptian Journal of Aquatic Research, 41, 353-358. https://doi.org/10.1016/j.ejar.2015.10.003

Laleye, P., Chikou, A., Gnohossou, P., Vandewalle, P., Phillippart, J.C., \& Teugels, G. (2006). Studies on the biology of two species of catfish, Synodontis schall and Synodontis nigrita (Ostariophysi mochokidae), from the Oueme River, Benin. Belgium Journal of Zoology, 136(2), 193-201.

Mehdinejad, N., Imanpour, M.R., \& Jafari, V. (2018). Combined or individual effects of dietary probiotic, Pediococcus acidilactici and nucleotide on reproductive performance in goldfish (Carassius auratus). Probiotics and Antimicrobial Proteins, 1-8. https://doi.org/ 10.1007/s12602-017-9297-3

Miccoli, A., Gioacchini, G., Maradonna, F., Benato, F., Skobo, T., \& Carnevali, O. (2015). Beneficial bacteria affect Danio rerio development by the modulation of maternal factors involved in autophagic, apoptotic and dorsalizing processes. Cellular Physiolology Biochemistry, 35(5), 1706-1718. https://doi.org/ 10.1159/000373983

Mikulski, D., Jankowski, J., Naczmanski, J., Mikulska, M., \& Demey, V. (2012). Effects of dietary probiotic (Pediococcus acidilactici) supplementation on performance, nutrient digestibility, egg traits, egg yolk cholesterol, and fatty acid profile in laying hens. Poultry Science, 91(10), 2691-2700.

Mukti, A.T., Carman, O., Alimuddin, Zairin Jr., M, Suprayudi, M.A. (2020a). Growth performance, survival rate, flesh, and proximate composition of sex-grouped triploid and diploid Nile tilapia (Oreochromis niloticus). Turkish Journal of Veterinary and Animal Sciences, 44(2), 290298. https://doi.org/10.3906/vet-1905-79

Mukti, A.T., Sari, Y.G.P., Agusdinata, G.S.R, Satyantini, W.H., Mubarak, A.S., Luqman, E.M., \& Widjiati. (2020b). The effects of laserpuncture on gonadal maturity and sperm quality of male striped catfish (Pangasianodon hypophthalmus). Theriogenology, 147, 102-107. https://doi.org/10.1016/j.theriogenology.2020.02.030

Nargesi, E.A., Falahatkar, B., \& Sajjadi, M.M. (2018). Dietary supplementation of probiotics and influence on feed efficiency, growth parameters, and reproductive performance in female rainbow trout (Oncorhynchus mykiss) broodstock. Aquaculture Nutrition, 00, 1-11. https://doi.org/10.1111/anu.12970

Qin, C., Xu, L., Yang, Y., He, S., Dai, Y., Zhao, H., \& Zhou, Z. (2013). Comparison of fecundity and offspring immunity in zebrafish fed Lactobacillus rhamnosus CICC 6141 and Lactobacillus casei BL23. Reproduction, 147, 1-13. https://doi.org/10.1530/REP-13-0141

Rahman, M.L., Akhter, S., Mallik, Md. K.M., \& Rashid, I. (2018). Probiotic enrich dietary effect on the reproduction of butter catfish, Ompok pabda (Hamilton, 1872). International Journal of Current Research in Life Sciences, 7(2), 866-873. 
Reid, J.N.S., Bisanz, J.E., Monachese, M., Burton, J.P., \& Reid, G. (2013). The rationale for probiotics improving reproductive health and pregnancy outcome. American Journal of Reproductive Immunology, 69, 558-566. https://doi.org/10.1111/aji.12086

Sakamole, E.T., Lumenta, C., \& Runtuwene, M. (2014). The effect of probiotic addition with different dosages in the feed on growth and feed conversion ratio of common carp (Cyprinus carpio) seed. Buletin Sariputra, 1(1), 2933.

Salerno, A.P., Marýlvi Dansa-Petretski, Ma'rio, A.C., SilvaNeto, Heloýsa, S.L., Coelho, \& Atisaburo, M. (2002). Rhodnius prolixus vitellin is composed of three different populations: comparison with vitellogenin. Insect Biochemistry and Molecular Biology, 32, 709-717. https://doi.org/10.1016/s0965-1748(01)00152-7

Sabet, S.S., Imanpoor, M.R., Fatideh, B.A, \& Gorgin, S. (2009). Study on sexual maturity and levels of gonad steroid hormones in female kutum (Rutilus frisii kutum)
Kamenskii, (1901) during spawning season from River Sefid-Rood of the Southern Caspian Sea. Journal of Cell Animal Biology, 3, 208-215.

Shinkafi, B.A., \& Ipinjolu, J.K. (2012). Gonadosomatic index, fecundity and egg size of Auchenoglanis occidentalis (Cuvier and Valenciennes) in River Rima, North-Western Nigeria. Nigerian Journal of Basic and Applied Science, 20(3), 217-224.

Taghizadeh, V., Imanpoor, M.R, \& Mehdinejad, N. (2013). Study the seasonal steroid hormones of common carp in Caspian Sea, Iran. Springerplus, 2, 193.

https://doi.org/10.1186/2193-1801-2-193

Tang, U.M., \& Affandy, R. (2000). Reproductive biology of fish. Pusat Penelitian Kawasan Pantai dan Perairan, Universitas Riau, Pekanbaru, Riau.

Younis, N., \& Mahasneh, A. (2020). Probiotics and the envisaged role in treating human infertility. Middle East Fertility Society Journal, 25, 33.

https://doi.org/10.1186/s43043-020-00039-y 